\title{
Hybrid Congenital Lung Malformation with Difficulty in Diagnosis and Treatment: Congenital Cystic Adenoid Malformation and Pulmonary Sequestration Co-existence
}

\section{Tanı veTedavide Zorluk Yaşatan Hibrid Konjenital Akciğer Malformasyonu: Konjenital Kistik Adenoid Malformasyon ve Pulmoner Sekestrasyon Birlikteliği}

Bengisu Arabacı, Kenan Can Ceylan, Nur Yücel, Seyda Ors Kaya

\begin{abstract}
Congenital abnormalities of the lung can manifest in any component of the bronchopulmonary system. Congenital lobar emphysema, bronchogenic cyst, congenital cystic adenoid malformation (CCAM) or pulmonary sequestration (PS) are just some of the many kinds of malformations of the lung. The coexistence of CCAM and PS is a very rare condition. Due to such complications as dyspnea or recurrent infection, most malformations are diagnosed antenatally or in the immediate postnatal period. The present case was not diagnosed until late adolescence, and the patient was subsequently referred to our clinic after undergoing a previous operation. After examinations and a preoperative evaluation, a second operation was performed. We present to literature a very rare case of co-existing CCAM and PS (hybrid lung malformation).
\end{abstract}

Key words: Congenital anomaly, surgery, hybrid malformation.

\section{Özet}

Akciğerin konjenital anomalileri bronkopulmoner sistemin tüm bileşenlerinden kaynaklanabilir. Konjenital lober amfizem, bronkojenik kist, konjenital kistik adenoid malformasyon (KKAM) veya pulmoner sekestrasyon (PS) bronkopulmoner malformasyonlardır. KKAM ve PS birlikte çok nadir görülmektedir. Solunum sıkıntısı, tekrarlayan enfeksiyonlar gibi komplikasyonlar nedeniyle çoğu antenatal veya postnatal dönemde tanı almaktadır. Erişkin yaşa kadar tanı ve tedavisinde sorunlar yaşanan bir olgu, ileri tanı ve tedavi amaçlı kliniğimize yönlendirildi. Tetkik ve değerlendirmeler sonrasında kliniğimizde ikinci kez operasyon yapıldı. Çok nadir görülen KKAM ve PS birlikteliği (hibrid konjenital malformasyon) saptanan olguyu literatür eşliğinde sunmayı amaçladık.

Anahtar Sözcükler: Konjenital anomali, cerrahi, hibrid malformasyon.
Department of Thoracic Surgery, University of Health Sciences Turkey Dr. Suat Seren Chest Diseases and Thoracic Surgery Medical Practice And Research Center, İmir, Turkey
S.B.Ü. Dr. Suat Seren Göğüs Hastalıkları Ve Göğüs Cerrahisi E.A.H., Göğüs Cerrahisi, İzmir

Submitted (Başvuru tarihi): 13.07.2020 Accepted (Kabul tarihi): 11.10.2020

Correspondence (iletişim): Bengisu Arabacı, Department of Thoracic Surgery, University of Health Sciences Turkey Dr. Suat Seren Chest Diseases and Thoracic Surgery Medical Practice And Research Center, Izmir, Turkey

e-mail: bengisuarabaci@hotmail.com

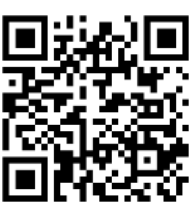


Congenital abnormalities of the lung can manifest in any component of the bronchopulmonary system. Congenital lobar emphysema, bronchogenic cyst, congenital cystic adenoid malformation (CCAM) or pulmonary sequestrations (PS) are just some of the many malformations of the lung. The co-existence of CCAM and PS is a very rare condition. As a result of complications like dyspnea or recurrent infection, most malformations are diagnosed antenatally or in the immediate postnatal period. This case in the present study was not diagnosed until late adolescence, and was subsequently referred to our clinic after undergoing a previous operation. After an examination and a preoperative evaluation, a second operation was performed. We present to literature a very rare case of co-existing CCAM and PS (hybrid lung malformation).

\section{CASE}

A 17-year-old patient presented to the Emergency Department with chest pain and dyspnea. The patient was evaluated as primary pneumothorax and a chest tube was inserted. An air leak was observed from day 1, lasting for more than a week. He was diagnosed as prolonged air leak into the chest cavity and underwent an exploratory thoracotomy about a year ago. A preoperative exploration identified a thick-walled hydatid cyst. The cystic fluid was aspirated and the cavity was closed, and was pathologically found to be compatible with benign tissue. A year later, the patient developed the same symptoms and was diagnosed with recurrent pneumothorax, and a tube thoracotomy was carried out. Upon clinical follow-up, the absence of improvement resulted in the case being referred to our clinic for further investigation. A computed tomography (CT) scan revealed branching from the abdominal aorta with vascularization variants in the cystic region in the right lower zone (Figure $1 a, b, c)$. The patient's laboratory values were insignificant, and infectious process was excluded in differential diagnosis. A second right thoracotomy was performed, and an exploration of the cystic malformed area revealed an immature bullous image that seemed to be independent of the bronchial and vascular structures of the lower lobe parenchyma. The malformed structure that had been receiving its blood supply from the abdominal aorta was excised from the lower lobe. Histopathologically, the cystic lung tissue showed fibrosis and smooth muscle hyperplasia and contained vascular components, and so was evaluated as a hybrid congenital lung malformation and intralobar sequestration (CCAM and ILS) due to its involvement in the normal lung parenchyma (Figure 2a). The patient is in his 8th month of postoperative follow-up and is recovering well (Figure 2c).

\section{DISCUSSION}

CCAM is a hamartoid cystic lung tissue that originates from parenchymal, vascular or bronchial anomalies, and is the most common of the congenital pulmonary airway malformations. While seen previously in $1 / 25,000$ 35,000 live births, it has been reported to be more common in recent studies $(1 / 7,200$ live births) $(1,2)$. Histopathologically, PS is a combination of the aberrant vascular component and dysfunctional abnormal lung tissue, and can be classified as intra-lobar or extra-lobar. It can be further defined as bronchial atresia with systemic vascularization (3). Congenital lung malformations are generally diagnosed by ultrasonography (USG) or magnetic resonance imaging (MRI) in the intrauterine period. Surgical excision is preferred in diagnosed patients due to the potential for infections or malignancies, even in asymptomatic cases (4). A review of literature reveals the majority of cases operated for congenital cystic lung malformations are below the age of 10 months (5), although patients diagnosed and operated during childhood have also been reported in rare cases (6). In our patient, congenital cystic lung malformation was not considered as a possible cause during the initial stage of the differential diagnosis due to his age. Due to the patient's increasing shortness of breath, the case was instead evaluated in favor of pneumothorax in the emergency department (Figure 2b).

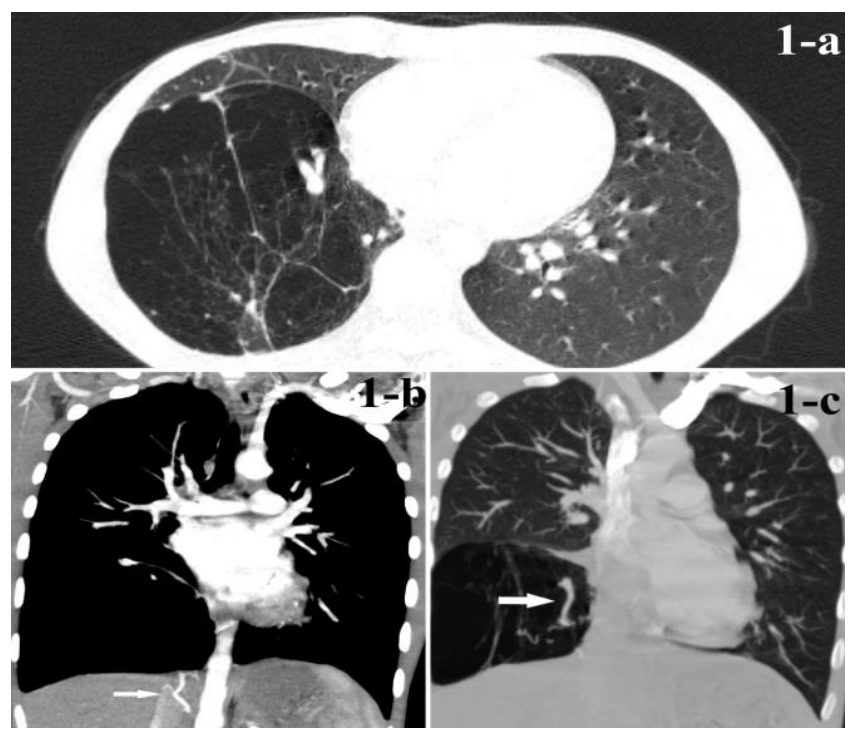

Figure 1: Cystic structure and aberrant vascularization observed in the right lower section on a thorax CT taken for preoperative evaluation (a), the aberrant vascular structure is seen to originate from the abdominal 
aorta on a thorax CT (b), vascularization of the cystic lesion was observed in the lower lobe (c)

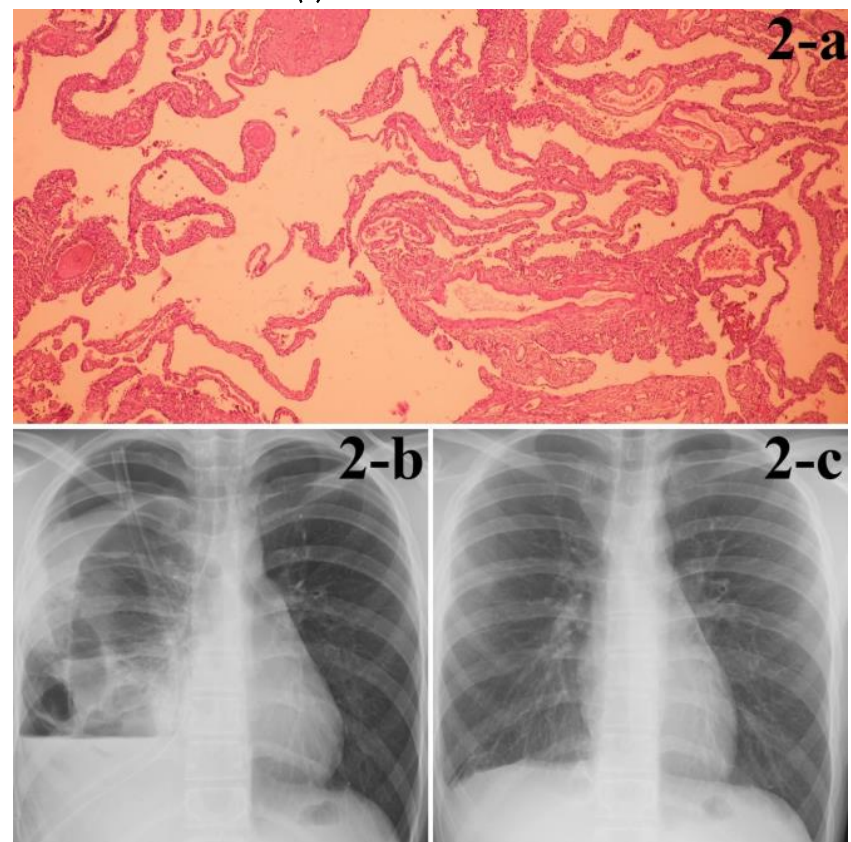

Figure 2: The cystic structure is seen to be surrounded by fibrous bands and accompanied by vascular structures at X100 magnification (a), preop posteroanterior chest radiography of the patient (b), postoperative 8th month control chest radiography (c)

The number of patients who remain asymptomatic for a long time is small. Asymptomatic cases without antenatal diagnosis are detected incidentally and operated for such reasons as recurrent infections and hemoptysis.

Attention should be paid to understanding the anatomical structures and vascular variants that may accompany. In studies conducted to date, contrast computed tomography $(C T)$ is recommended prior to operation to understand correctly the anatomy of the thorax, the structure of the lung parenchyma and vascularity, and it has been observed that CT largely overlaps with pathology (7). In a contrast CT of the patient in the present study taken before the operation, variants of vascularization in the right lower lobe cystic region were observed, branching from the abdominal aorta (Figure $1 \mathrm{~b}, \mathrm{c}$ ).

The surgeon should be aware that the blood supply of the cystic lesion may be systemic and that fissure anomalies may be encountered also in the lung, and the operation approach should be selected with this in mind. The thoracoscopic method is preferred mostly in asymptomatic neonatal or pediatric cases, and the results are generally satisfying $(4,8)$. A 17 -year-old underwent a thoracostomy with a pre-diagnosis of pneumothorax, and after that he was explored with a right thoracotomy due to prolonged air leak into the chest cavity. The patient was referred to our clinic for further examination due to a lack of improvement in his medical condition. A re-operation was made after the examination. Considering the medical history of the patient, we opted to perform a rethoracotomy during the operation to visualize the aberrant vascular structures accompanying the cystic structure that could be seen in the thorax CT (Figure 1a). Soft pathological tissue with severe adhesion and aberrant vascular structures was excised, and a histopathological examination revealed it to be a hybrid congenital lung malformation (CCAM and ILS) (Figure 2a), which led us to present this very rare case to medical literature. We are pleased to report that at postoperative follow-up, the patient was symptom-free (Figure 2c).

Hybrid congenital lung anomalies are usually excised surgically having become symptomatic in the postnatal period, and have the potential for malignancy. Since our patient was in late adolescence, difficulties were observed during diagnosis and treatment. Rare hybrid congenital lung malformations should be considered in children and young adults with persistent respiratory distress and recurrent signs of infection. It is important to evaluate cases that will benefit from surgical excision in this regard.

\section{CONFLICTS OF INTEREST}

None declared.

\section{AUTHOR CONTRIBUTIONS}

Concept - B.A., K.C.C., N.Y., S.O.K.; Planning and Design - B.A., K.C.C., N.Y., S.O.K.; Supervision - B.A., K.C.C., N.Y., S.O.K.; Funding -; Materials - N.Y., K.C.C.; Data Collection and/or Processing - B.A., K.C.C.; Analysis and/or Interpretation - B.A., K.C.C., S.O.K.; Literature Review - B.A., K.C.C., S.O.K.; Writing - B.A., K.C.C.; Critical Review - B.A., K.C.C.

\section{YAZAR KATKILARI}

Fikir - B.A., K.C.C., N.Y., S.O.K.; Tasarım ve Dizayn B.A., K.C.C., N.Y., S.O.K.; Denetleme - B.A., K.C.C., N.Y., S.O.K.; Kaynaklar -; Malzemeler - N.Y., K.C.C.; Veri Toplama ve/veya İşleme - B.A., K.C.C.; Analiz ve/veya Yorum - B.A., K.C.C., S.O.K.; Literatür Taraması - B.A., K.C.C., S.O.K.; Yazıyı Yazan - B.A., K.C.C.; Eleştirel İnceleme - B.A., K.C.C.

\section{REFERENCES}

1. Laberge JM, Flageole H, Pugash D, Khalife S, Blair G, Filiatrault D, et al. Outcome of the prenatally diagnosed congenital cystic adenomatoid lung malformation: a Canadian experience. Fetal Diagn Ther 2001; 16:178-86. [CrossRef] 
2. Lau CT, Kan A, Shek N, Tam P, Wong KK. Is congenital pulmonary airway malformation really a rare disease? Result of a prospective registry with universal antenatal screening program. Pediatr Surg Int 2017; 33(1):105-8. [CrossRef]

3. Fowler DJ, Gould SJ. The pathology of congenital lung lesions. Semin Pediatr Surg 2015; 24:176-82. [CrossRef]

4. Thakkar H, Durell J, Chakraborty S, Tingle BL, Choi A, Fowler DJ, et al. Antenatally detected congenital pulmonary airway malformations: The Oxford experience. Eur J Pediatr Surg 2017; 27:324-9. [CrossRef]

5. Stanton M, Niere I, Ade-Ajayi N, Patel S, Davenport M. Systematic review and meta-analysis of the postnatal management of congenital cystic lung lesions. J Pediatr Surg 2009; 44:1027-33. [CrossRef]
6. Naumeri F, Saijad MN. Hybrid lesion: Extralobar sequestration with cystic adenomatoid malformation- misdiagnosed as pulmonary tuberculosis. J. Coll Physicians Surg Pak 2018; 28:204-6. [CrossRef]

7. Mon RA, Johnson KN, Ladino-Torres $M$, Heider $A$, Mychaliska GB, Treadwell MC, et al. Diagnostic accuracy of imaging studies in congenital lung malformations. Arch Dis in Child Fetal Neonatal Ed 2019; 104:F372-77. [CrossRef]

8. Nakata M, Yoshida S, Saito T, Terui K, Mitsunaga T, Ohno $S$, et al. Hybrid video-assisted thoracoscopic surgery lobectomy of fissureless congenital cystic adenomatoid malformation: a case report. J Med Case Rep 2015; 9:23. [CrossRef] 